\title{
Pelaksanaan Itsbat Nikah Di Pengadilan Agama Sorong
}

\author{
Rajab Lestaluhu \\ Fakultas Hukum, Universitas Muhammadiyah Sorong \\ Email : Rajablesta@gmail.com
}

\begin{abstract}
Abstrak
Penelitian ini bertujuan Untuk mengetahui Pelaksanaan Itsbat Nikah di Pengadilan Agama Sorong. Untuk mengetahui Dasar Pertimbangan Hakim dalam memberikan penetapan mengenai Itsbat Nikah di Pengadilan Agama Sorong.

Penelitian ini dilaksanakan di Pengadilan Agama Sorong, Penelitian ini menggunakan pendekatan pendekatan yuridis empiris, kemudian tekhnik pengumpulan data dengan cara wawancara Majelis Hakim Pengadilan Agama dan Panmud Permohonan dan studi dokumen-dokumen atau bahan pustaka yang menyangkut data yang di perlukan.

Hasil penelitian mengenai pelaksanaan Itsbat Nikah di Pengadilan Agama Sorong setelah berlakunya Undang-Undang Nomor 1 Tahun 1974 yaitu secara keseluruhan tahap dan prosedurnya sudah sesuai dengan hukum Acara Peradilan Agama sebagaimana yang ada dalam HIR / R.Bg. dan Peraturan perundang-undangan yang berlaku. Secara keseluruhan prosedur pengajuan perkara itsbat nikah yang sudah berjalan di Pengadilan Agama Sorong dapat dikelompokkan menjadi (5) lima yaitu mendaftar ke Kantor Pengadilan Agama Sorong, membayar panjar biaya perkara, menunggu panggilan sidang dari pengadilan, menghadiri persidangan dan putusan pengadilan.
\end{abstract}

Kata Kunci : Istbat Nikah, Pengadilan Agama

\section{PENDAHULUAN}

Perkawinan merupakan suatu peristiwa penting dalam kehidupan manusia, karena perkawinan tidak saja menyangkut pribadi kedua calon suami istri, tetapi juga menyangkut urusan keluarga dan masyarakat. Pada umumnya perkawinan dianggap sebagai sesuatu yang suci dan karenanya setiap agama selalu menghubungkan kaedah-kaedah perkawinan dengan kedah-kaedah agama. Manusia dalam menempuh pergaulan hidup dalam masyarakat ternyata tidak dapat terlepas dari adanya saling ketergantungan antara manusia dengan manusia yang lainnya. Hal itu dikarenakan sesuai dengan kedudukan manusia sebagai mahluk sosial yang suka berkelompok atau berteman dengan manusia lainnya. Hidup bersama merupakan salah satu sarana untuk memenuhi kebutuhan hidup manusia baik kebutuhan yang bersifat jasmani maupun yang bersifat rohani. Aturan tata-tertib perkawinan sudah ada sejak masyarakat sederhana yang dipertahankan oleh anggota-anggota masyarakat dan para pemuka masyarakat adat dan atau para pemuka agama. Aturan tata-tertib itu terus berkembang maju dalam masyarakat yang mempunyai kekuasaan pemerintahan dan di dalam suatu negara.

Di indonesia aturan tata-tertib perkawinan itu sudah ada sejak zaman kuno, sejak zaman sriwijaya, majapahit, sampai masa colonial belanda dan sampai indonesia telah merdeka. Budaya perkawinan dan aturannya yang berlaku pada suatu masyarakat atau pada 
suatu bangsa tidak terlepas dari pengaruh budaya dan lingkungan dimana masyarakat itu berada serta pergaulan masyarakatnya. Seperti halnya aturan perkawinan bangsa indonesia bukan saja dipengaruhi adat budaya masyarakat setempat, tetapi juga dipengaruhi ajaran agama Islam, Hindu, Budha dan Kristen.

Di satu sisi Peraturan Perundang-Undangan Indonesia menyatakan pencatatan perkawinan merupakan satu-satunya alat bukti telah terjadinya perkawinan, namun di sisi lain perundang-undangan memberi jalan keluar bagi orang-orang yang tidak dapat membuktikan adanya perkawinan tersebut dengan jalan Penetapan Nikah (Itsbat Nikah) dari Pengadilan Agama, sebagaimana diatur dalam Pasal 7 ayat (2) Kompilasi Hukum Islam yang menyatakan "Dalam hal perkawinan tidak dapat dibuktikan dengan Akta Nikah, dapat diajukan Itsbat Nikah-nya ke Pengadilan Agama" Sebagai contoh masalah isbat nikah dalam pasal 7 ayat 3d kompilasi hukum islam (KHI) menjelaskan bahwa itsbat nikah yang diajukan di pengadilan agama terbatas ketika adanya perkawinan yang terjadi sebelum berlakunya UU No.1 Tahun 1974.

Kehati-hatian hakim dalam mengambil sikap terhadap penetapan permohonan itsbat nikah sangat diperlukan, hal ini sebagai upaya mengantisipasi dalam pengajuan permohonan itsbat nikah atas pernikahan dibawah tangan atau praktek poligami liar diluar ketentuan yang dibenarkan. Selain itu juga hakim perlu mempertimbangkan ketertiban dalam pencatatan perkawinan terlepas dari pelanggaran terhadap pasal 2 ayat 2 UU perkawinan untuk tegaknya hukum perkawinan di Indonesia.

Dalam hal penetapan permohonan itsbat nikah hanya diberlakukan Sesuai dengan ketentuan dalam KHI pasal 7. Namun ternyata permohonan itsbat nikah di Pengadilan Agama Sorong hampir semua ditetapkan dengan motif pengajuan permohonan berbeda dengan apa yang ditentukan dalam KHI, walaupun Undang-undang dan peraturan sudah menegaskan demikian namun sampai sekarang masih banyak dikalangan masyarakat kota sorong yang pernikahannya tidak tercatat di Pegawai Pencatat Nikah Kantor Urusan Agama walaupun kantor urusan agama di kota sorong masih dapat di jangkau oleh masyarakat.

Permasalahan ini merupakan permasalahan yang menarik untuk dikaji, dikarenakan mengingat pada saat ini banyaknya masyarakat kota sorong yang belum memahami pentingnya kepastian hukum terutama dalam hal perkawinan, ini dikarenakan kurangnya kesadaran hukum di masyarakat sehingga masih banyaknya ditemui pasangan suami istri yang pernikahannya tidak tercatat, yang kemudian penulis tertarik untuk melakukan penelitian di Pengadilan Agama Sorong yang mempunyai kewenangan menetapkan 
permohonan itsbat nikah tersebut. Berdasarkan latar belakang di atas, maka penulis selanjutnya merumuskan masalah pokok dalam skripsi ini adalah sebagai berikut : (a) Bagaimana pelaksanaan Itsbat Nikah di Pengadilan Agama Sorong? (b) Apa dasar Pertimbangan Hakim dalam memberikan Penetapan Itsbat Nikah di Pengadilan Agama Sorong setelah berlakunya UU No.1 Tahun 1974 ?

\section{PEMBAHASAN}

\section{Pertimbangan Hakim Dalam Memberikan Penetapan Isbat Nikah Di Pengadilan Agama Sorong}

Setelah diberlakukannya Undang-undang No. 1 Tahun 1974 tentang perkawinan, peraturan-peraturan yang ada dinyatakan tidak berlaku lagi sepanjang telah diatur dalam UU tersebut. UU No. 1 Tahun 1974 merupakan undang-undang yang bersifat nasional yang berlaku bagi seluruh warga negara indonesia baik yang diluar negeri maupun dalam negeri. UU No. 1 Tahun 1974 juga berlaku bagi semua pemeluk agama yang diakui di indonesia.

Perkawinan menimbulkan hak dan kewajiban bagi suami,istri dan anak-anak. Untuk terjamin dan terlindunginya pelaksanaan hak dan kewajiban tersebut, sahnya suatu perkawinan menjadi sangat penting dan menentukan perkara yang akan timbul di kemudian hari dalam suatu perkawinan tersebut, hak-haknya akan mendapatkan perlindungan hukum, bilamana status perkawinan sah menurut Syariat Islam dan perundang-undangan yang berlaku di Indonesia.

UU No.1 Tahun 1974 tentang perkawinan telah menentukan bahwa.; (1) Perkawinan adalah sah apabila dilaksanakan menurut hukum masing-masing agamanya dan kepercayaan itu (pasal 2 (1)).; (2) Tiap-tiap perkawinan dicatat menurut peraturan perundang-undangan yang berlaku (pasal 2(2)).

Berdasarkan ketentuan pasal diatas, dapat di pahami oleh umat islam di indonesia bahwa perkawinan yang sah dan mendapatkan perlindugan hukum ialah perkawinan yang dilakukan dengan syariat islam yang telah memenuhi rukun dan syarat perkaiwanan yang dilakukan di hadapan Pegawai Pencatatan Nikah (PPN) dan dicatat sesuai dengan undangundang yang berlaku. Sehingga suami-istri memperoleh Akte nikah (Buku Nikah).

Perkawinan yang hanya dilakukan menurut ketentuan syariat islam tanpa dilakukan pencatatan nikah yang telah di kehendaki oleh UU No.1 Tahun 1974 tentang perkawinan maka disebut perkawinan di bawah tangan atau biasa di sebut nikah sirri, Di indonesia perkaiwan sirri tidak mendapatkan perlindungan hukum. 
Nikah di bawah tangan yang biasa di sebut nikah yang dilakukan secara sembunyisembunyi atau nikah sirri, tidak dicatatkan pada petugas Pencatatan Nikah (PPN) dan tidak terdaftar di Kantor Urusan Agama (KUA) sehingga tidak mempunyai bukti otentik sehingga perkawinannya tidak mempunyai kekuatan hukum karena di dalam Undang-undang No.1 Tahun 1974 tidak mengatur mengenai perkawinan yang tidak di catat.

Upaya hukum yang dilakukan untuk mendapatkan pengakuan hukum atau pengakuan negara terhadap perkawinan yang tidak dicatat yaitu melalui pengesahan nikah atau itsbat nikah. Pengesahan atau Itsbat nikah merupakan istilah baru dalam fiqh munakahat, yang secara harfiah berarti "penetapan", atau "pengukuhan” nikah.

Dalam hal ini kompilasi hukum islam membuka kesempatan kepada mereka untuk mengajukan permohonan itsbat nikah (penetapan nikah) kepada Pengadilan Agama sehingga yang bersangkutan mempunyai kekuatan hukum dalam ikatan perkawinannya. Pasal 7 ayat (2) dan (3) mengungkapkan sebagai berikut, (Ayat 2) dalam hal perkawinan tidak dapat dibuktikan dengan akta nikah, dapat diajukan itsbat nikahnya ke Pengadilan Agama.; (Ayat 3) itsbat nikah yang dapat diajukan ke Pengadilan Agama terbatas mengenai hal-hal yang berkenaan dengan.; (a) Adanya perkawinan dalam rangka penyelesaian perceraian.; (b) Hilangnya akta nikah.; (c) Adanya keraguaan tentang sah atau tidaknya salah satu syarat perkawinan.; (d) Adanya perkawinan yang terjadi sebelum berlakunya undang-undang Nomor 1 tahun 1974.; (e) Perkawinan yang dilakukan oleh mereka yang tidak mempunyai halangan perkawinan menurut undang-undang nomor 1 tahun 1974.

Pasal diatas memberikan jalan untuk mengajukan itsbat nikah. Tujuan diberikannya kesempatan untuk mengajukan itsbat nikah ini adalah melindungi hak-hak para pihak yang terkait dalam perkawinan tersebut secara hukum. Pihak Pengadilan Agama sendiri dalam memberikan penetapan juga harus melalui pertimbangan yang didasarkan pada bukti-bukti yang kuat dan keterangan saksi yang membenarkan telah dilakukannya perkawinan.

Dalam hal ini, Kehati-hatian hakim dalam mengambil sikap terhadap penetapan permohonan itsbat nikah sangat diperlukan, hal ini sebagai upaya mengantisipasi dalam pengajuan permohonan itsbat nikah atas pernikahan dibawah tangan atau praktek poligami liar diluar ketentuan yang dibenarkan. Selain itu juga hakim perlu mempertimbangkan ketertiban dalam pencatatan perkawinan terlepas dari pelanggaran terhadap pasal 2 ayat $2 \mathrm{UU}$ perkawinan untuk tegaknya hukum perkawinan di Indonesia.

Permohonan pengesahan nikah bagi perkawinan yang tidak tercatat yang dilakukan pada saat sebelum berlakunya Undang-Undang Nomor 1 Tahun 1974 sepanjang memenuhi 
persyaratan, dalam prakteknya, Pengadilan Agama mengabulkan. Namun demikian permohonan pengesahan nikah bagi pernikahan di bawah tangan (tidak tercatat) yang dilakukan pada saat setelah berlakunya Undang-Undang Nomor 1 Tahun 1974 tersebut masih dikabulkan karena berbagai kendala atau hambatan.

Dalam hal ini penulis mencermati mengenai tingkat keberhasilan permohonan pengesahan nikah di Pengadilan Agama (dikabulkan atau ditolak) sepenuhnya menjadi kewenangan hakim yang menyidangkan perkaranya setelah meneliti data persyaratan yang diajukan pemohon. Tentu saja disetiap Pengadilan Agama berbeda dalam member penetapan, karena sifatnya kasuistis. Semua dikembalikan pada hati nurani para hakim dalam memberi rasa keadilan bagi pemohon.

\section{SIMPULAN}

Dari hasil penelitian dan pembahasan sebagaimana dipaparkan di atas, maka dapat ditarik beberapa kesimpulan sebagai berikut.; (1) Pelaksanaan Itsbat Nikah di Pengadilan Agama Sorong adalah Prosedur pengajuan perkara itsbat nikah di Pengadilan Agama Sorong serta dengan menganalisis perkata itsbat nikah yang masuk disana bahwa secara keseluruhan tahap dan prosedurnya sudah sesuai dengan hukum Acara Peradilan Agama sebagaimana yang ada dalam HIR / R.Bg. dan Peraturan perundang-undangan yang berlaku. Secara keseluruhan prosedur pengajuan perkara itsbat nikah yang sudah berjalan di Pengadilan Agama Sorong dapat dikelompokkan menjadi (5) lima yaitu mendaftar ke Kantor Pengadilan Agama Sorong, membayar panjar biaya perkara, menunggu panggilan sidang dari pengadilan, menghadiri persidangan dan putusan pengadilan.; (2) Dasar Pertimbangan Hakim dalam memberikan Penetapan Itsbat Nikah di Pengadilan Agama Sorong setelah berlakunya UU No.1 Tahun 1974 adalah dalam menetapkan perkara Itsbat nikah yang masuk di pengadilan agama sorong, Majelis Hakim mempunyai pertimbangan-pertimbangan yang sangat kuat untuk menetapkan perkara itsbat nikah yang perkawinannya tidak di catat Oleh Pegawai Pencatatan nikah (PPN) dari Kantor Urusan Agama Setempat walaupun perkawinan tersebut terjadi sesudah berlakunya Undang-undang Nomor 1 Tahun 1974 Tentang Perkawinan. Diantaranya Majelis Hakim melihat berdasarkan bukti-bukti yang ada selama persidangan dan mencocokkan keterangan para saksi apakah sesuai dengan posita (fakta hukum).

\section{DAFTAR PUSTAKA}

Al-Instanbul, Mahmud Mahdi. 2010. Bekal Pengantin. Solo: Aqwam

Ali, Zainuddin, 2006. Hukum Perdata Islam. Jakarta: Sinar Grafika

Ali, Achmad dan Wiwie Heryani, 2012. Asas-asas Hukum Pembuktian Perdata, Jakarta: Kencana 
Hatadimaja, Harumiati. 2009. Hukum Perdata Mengenai Hukum Perorangan dan Hukum Benda, Yogyakarta: Graha Ilmu

Hadikusuma, Hilman. 2007. Hukum perkawinan indonesia. Bandung: Mandar Maju

Komariah, 2011. Hukum Perdata. Malang: UMM Press

Laporan Tahunan Pengadilan Agama Sorong 2016,2017,2018

Mardani, 2011. Hukum Perkawinan Islam Di dunia islam Modern. Yogyakarta: Graha Ilmu

Nasution, Bahder Johan dan Sri Warjiyati. 1997. Hukum Perdata Islam. Bandung: Mandar Maju

Salim. 2001. Pengantar Hukum Perdata Tertulis (BW). Jakarta: Sinar Grafika

Syafrianto, Dian. 2013. pelaksanaan isbat nikah di pengadilan agama semarang setelah berlakunya undang-undang nomor 1 tahun 1974. Semarang: Skripsi

R. Soeroso, 2014. Hukum Acara Perdata. Jakarta: Sinar Grafika

Syarifuddin, Amir. 2007. Hukum Perkawinan Islam Di Indonesia. Jakarta: Kencana

Sugeng, Bambang dan Sujayadi. 2012. Pengantar Hukum Acara Perdata, Jakarta: Kencana

Sunggono, Bambang. 2007. Metodologi penelitian hukum. Jakarta: Rajagrafindo persada

Wardah, Sri dan Bambang Sutiyoso. 2007. Hukum Acara Perdata dan Perkembangannya Di Indonesia. Yogyakarta: Gama Media

Zainuddin dan Afwan Zainuddin, 2017. kepastian hukum perkawinan siri dan permasalahannya ditinjau dari undang-udang nomor 1 tahun 1974. Yogyakarta: CV. Budi Utama

Undang-undang No. 1 Tahun 1974 Tentang Perkawinan

Undang-Undang Republik Indonesia Nomor 3 Tahun 2006 Tentang Perubahan Atas Undang-Undang Nomor 7 Tahun 1989 Tentang Peradilan Agama 